Магдисюк Людмила кандидат психологічних наук, доцент кафедри практичної та клінічної психології Східноєвропейського національного університету імені Лесі Українки; http://orcid.org/0000-0002-5304-933X

Павлова Богдана здобувач другого (магістерського) ступеня факультету психології та соціології Східноєвропейського національного університету імені Лесі Українки

Гнатойко Ірина здобувач першого (бакалаврського) ступеня факультету психології та соціології Східноєвропейського національного університету імені Лесі Українки

DOI https://doi.org/10.35619/prap_rv.vi14.163

\title{
МЕДИКО-ПСИХОЛОГІЧНЕ КОНСУЛЬТУВАННЯ ОСІБ 3 СЕРЦЕВО- СУДИННИМИ ЗАХВОРЮВАННЯМИ
}

Анотація. Стаття присвячена теоретичному аналізу особливостей медикопсихологічного консультування осіб з серчево-судинними захворюваннями. Розглянуто основні характеристики сериево-судинних захворювань, їх вплив на загальне самопочуття та здоров'я людини. Також, проаналізовано психологічні фактори, котрі провокують та загострюють перебіг сериево-судинних захворювань. Наведені результати емпіричного дослідження свідчать про вплив психологічних особливостей особистості, таких як схильність до переживання страху, негативне емоційне самопочуття, настрій на розвиток сериево-судинних захворювань. Відповідно, важливим $\epsilon$ врахування ичих особливостей під час медико-психологічного консультування осіб із даними захворюваннями, щзо в свою чергу, дозволить покрашити загальний та психологічний стан особистості. Отримані емпіричні дані можуть бути використані при консультативній роботі з клієнтами, котрі хворіють на серцево-судинні захворювання, для профілактики циих захворювань, за рахунок підвищення впевненості, покращення загального самопочуття, зменшення стресових проявів. Також і під час безпосередньої медико-психологічноі консультації осіб із сериево-судинними захворюваннями для зменшення їх негативного впливу на самопочуття, психологічне та фізичне здоров'я. Теоретико-емпіричні дані можуть використовуватися практичними психологами не лише в консультуванні, з метою надання кваліфікованої психологічної допомоги клієнтам з сериево-судинними захворюваннями, а й для самоосвіти та просвітницької діяльності усіх верств населення.

Ключові слова: емочиї, медико-психологічне консультування, хвороба, стрес, серцевосудинні захворювання, здоров'я.

Постановка проблеми. Проблема кваліфікованої психологічної допомоги при роботі із особами із серцево-судинними захворюваннями $\epsilon$ однією із актуальних в умовах сучасного розвитку суспільства, тому важливим є дослідження виникнення серцево-судинних захворювань, особливостей їх прояву, генезу саме у наш час. Актуальність цієї проблеми визначається взаємозв'язком психологічних особливостей людини i ïx впливом на виникнення серцевосудинних захворювань, тому важливим є якісне психологічне консультування.

Аналіз останніх досліджень 3 проблеми. Аналіз вітчизняних та зарубіжних робіт, на сьогоднішній день, підтвердив те, що проблема особливостей медико-психологічного консультування осіб із серцево-судинними захворюваннями досить мало досліджена. Проте, варто зазначити, що багатьма дослідниками встановлено, що у хворих 3 проблемами серця спостерігаються психічні зміни. Часто виникають такі емоційні порушення, як тривога, 
пригніченість, фіксація на своїх відчуттях і переживаннях, пов'язаних зі страхом смерті, втратою самоідентичності, почуття власного «Я» (Сисоєва, 2008, с. 25-52).

Як зазначає Моріц (2011) серцево-судинні хвороби - це результат відношення до власного здоров'я, від характеристик якого залежить життєдіяльність в цілому пацієнт розглядається як особистість, що під впливом хвороби змінюється і повертається до соціуму в іншому статусі хворої людини. Основні положення щодо вивчення даної проблеми характеризуються взаємозв'язком психічного та фізичного, їх правильним балансом. В контексті медикопсихологічного консультування, важливим $є$ досягнення гармонії між психічним та фізичним за для подолання серцево-суддиних захворювань.

Мета статті. Теоретико-емпіричний аналіз взаємозв'язку психологічних особливостей особистості та виникнення серцево-судинних захворювань; особливості медико-психологічного консультування осіб із серцево-судинними захворюваннями для профілактики та зниження їх проявів у хворих.

Виклад основного матеріалу дослідження. Важливою складовою професійної компетентності практичного психолога під час медико-психологічного консультування є вміння встановлювати професійні цілі та підбирати засоби для їх досягнення. Вибір вихідної теоретичної позиції для здійсненння професійного впливу на внутрішній світ іншої людини є для консультанта головним моментом вирішення питання про зміст взаємодії з клієнтом (Магдисюк, \& Федоренко, 2019). Під час медико-психологічного консультування осіб із серцево-суддиними захворюваннями важливим є врахування не лише психологічних особливостей особистості, але й їі фізичного стану - стану здоров'я. Мається на увазі, на скільки фізичне здоров'я людини дозволяє психологу працювати із клієнтом за для покращення чи нормалізації загального його стану. Тому, важливо чітко розуміти саме поняття «здоров'я» та «психологічне здоров'я». Здоров'я - це вихідна умова активної і нормальної життєдіяльності людини. Серйозні порушення у цій сфері спричиняють зміни у звичному способі життя людини, налагодженій системі відносин з навколишнім світом, можливу втрату професійної дієздатності, а загалом - вимушену корекцію планів на майбутнє. Здоров'я на психологічному рівні пов'язане з особистістю людини. Психічне здоров'я може бути порушене домінуванням негативних за своєю сутністю рис характеру, дефектами у моральній сфері, неправильним вибором ціннісних орієнтацій тощо (Белінська, 1983).

Медико-психологічне консультування осіб із серцево-судинними захворюваннями перш за все, зобов'язує психолога чітко оперувати поняттям, різновидами, особливостями серцевосудинних захворювань. Серцево-судинні захворювання пов'язані 3 патологією серця або кровоносних судин це загальна назва захворювань системи кровообігу (Магдисюк, \& Федоренко, 2019). 3 функціональної точки зору серцево-судинна система утворена двома спорідненими структурами. Перша складається з серця, артерій, капілярів та вен, які забезпечують замкнений колообіг крові, інша - 3 сітки капілярів й протоків, що впадають у венозну систему (Дроздова, Храмцова, Гончар, \& Яновська, 2015, с. 13-17). Рівень артеріального тиску - основний фактор руху крові, що залежить від роботи серця і тонусу судин. У свою чергу діяльність серцевосудинної системи змінюється залежно від потреб, сигналів організму, регулюється спеціальними нервовими центрами головного й спинного мозку, розгалуженнями (Белінська, 1983; Дроздова, Храмцова, Гончар, \& Яновська, 2015, с. 13-17). Підвищений артеріальний тиск, або гіпертонія, сьогодні вважається найбільш поширеним хронічним захворюванням. Загальновідомо, що вона $\epsilon$ основним фактором ризику в розвитку інсультів, інфарктів міокарда, пошкоджень судин та інших небезпечних захворювань (Дроздова, Храмцова, Гончар, \& Яновська, 2015, с. 13-17). Як правило, гіпертонічна хвороба прогресує поступово, у зв'язку з чим людина не помічає підвищеного артеріального тиску до тих пір, поки не виникнуть ускладнення - інфаркт або інсульт. Здоровий організм регулює артеріальний тиск самостійно. Однак надмірні фізичні навантаження, стрес, шкідливі звички, можуть порушити цей процес, особливо у генетично схильних до гіпертонії людей. Психологічні чинники, такі як стрес, депресії, нервова збудженість, надмірні хвилювання також провокують і ускладнюють серцево-судинні захворювання. Не можна не враховувати i взаємодію цих факторів, мається на увазі те, що психологічні чинники можуть поєднуватися із фізичними, що погіршить ще більше стан людини (Белінська, 1983). 
Здійснюючи характеристику причин виникнення серцево-судинних захворювань, варто зауважити, що багато хвороб виникають внаслідок перенапруги, від неможливості розрядити свої негативні емоції, які, у свою чергу, здійснюють безповоротні зміни. До основних психологічних факторів належить стрес. Стрес - поняття, яке використовується для позначення широкого спектру станів людини, які виникають як відповідь на різноманітні екстремальні чинники. Натомість стресором вважається фактор, що провокує почуття дисгармонії, дискомфорту тощо. Даний чинник у багатьох випадках загрожує не лише розвитком серцевих захворювань, а й раптовим їх загостренням (Магдисюк, 2014, с. 168-178). Важливе значення у розвитку серцевосудинних захворювань належить негативним емоціям, оскільки вони часто стають причиною несподіваної смерті при патологічному стані, який сам собою не загрожує життю хворих, що обов'язково повинні враховувати психологи при медико-психологічному консультуванні таких клієнтів (Магдисюк, 2016, с. 144-149).

Серцево-судинні захворювання мають негативний вплив на стан психічного здоров'я особистості. Щоб краще зрозуміти, яка психологічна допомога необхідна хворим на серцевосудинні захворювання, треба врахувати особистість пацієнта - це і є головним завданням медикопсихологічного консультування. Тому доцільно враховувати і психологічні, і фізичні особливості людини, котра має порушення у серцево-судинній сфері: емоції, переживання, стреси, як впливають на фізичне самопочуття та навпаки - усвідомлення хвороби, які викликає емоції: боязнь, страх тощо. Коли психолог врахує усі ці особливості у своїй діяльності під час медикопсихологічного консультування, то воно буде успішним (Засєкіна, \& Магдисюк, 2018).

Варто зазначити й те, що при чіткому дотриманні особливостей консультативного процесу, до яких відносимо налагодження довірливої атмосфери, конфіденційність, техніки активного слухання, перефразування тощо, потрібно розуміти і те, що саме такі клієнти потребують певного індивідуального підходу, оскільки у них на фоні серцево-судинних хвороб можуть бути порушення емоційної сфери, поведінки. Тому важливо, що клієнт мав бажання працювати, покращувати свій і емоційний, і фізичний стан, був відвертим, позитивно емоційно налаштованим. Саме для цього, при медико-психологічному консультуванні практичний психолог, може проявити емпатію, бажання допомогти, не забуваючи при цьому про те, що успіх усього консультативного процесу залежить від самого клієнта. Також, важливо підібрати той діагностичний інструментарій, який буде дозволяти психологу оцінити вище описані психологічні стани і тоді вже правильно обирати методи та техніки роботи, відповідно, до виявлених станів клієнта (Магдисюк, \& Федоренко, 2019; Моріц, 2011).

Спираючись на проаналізовані теоретичні особливості виникнення серцево-судинних захворювань, їх характеристику, психологічні та фізичні чинники, ми дійшли до логічного висновку, що медико-психологічне консультування осіб із такими порушеннями потребує, перш за все, компетентності практичного психолога, що включає в себе знання фізичних особливостей захворювань, їх психологічних проявів та особливостей їх взаємодії. Також, важливим $\epsilon$ дотримання усіх етапів консультативного процесу, але певною мірою, «підлаштовування» їх до особливої категорії осіб - клієнтів із серцево-судинними захворюваннями (Белінська, 1983; Засєкіна, \& Магдисюк, 2018; Магдисюк, \& Федоренко, 2019; Моріц, 2011). На основі теоретичного дослідження, нами було проведено емпіричне дослідження, котре спрямовувалося на виявлення психологічних особливостей осіб із серцево-судинними захворюваннями. Дослідження проводилося протягом 2019-2020 рр. на базі КП «Луцький центр первинної медичної допомоги №2» Волинської області. У дослідженні брали участь пацієнти з хворобами серцево-судинної системи. Продіагностовано 60 осіб, з них 30 - віком 40-59 років (І група - 15 чоловіків та 15 жінок), як представників пізньої зрілості та 30 - віком 60-79 (II група) - 15 чоловіків та 15 жінок, як представників похилого віку, у яких в анамнезі зазначалися серцево-судинні захворювання (такі як аритмія, гіпертонія, інсульт, варикозне розширення вен та ін.). Такий вибір зумовлений прагненням до підтвердження впливу вікового фактору на оцінку особами якості власного здоров'я. А також для формування порівняльної характеристики сприйняття життя досліджуваними різного віку, дані якої можна використовувати при медико-психологічному консультуванні даної категорії клієнтів. 
У I групі діагностованих, за шкалою «Самопочуття» найбільша кількість осіб (40\%) виявили середній рівень визнання негативних змін у стані здоров'я. Високі позитивні показники за шкалою самопочуття були діагностовані у третини учасників (33\%). Ці респондентиі визначають своє здоров'я як «відмінне». Низький рівень самопочуття задекларували $28 \%$ опитаних, що свідчить про посередній вплив хвороби на якісну оцінку самопочуття. Проте, згідно 3 результатами більшість із опитаних прагнули вибирати вищі бали, що ілюструє загальну тенденцію до визнання кращого стану самопочуття, хоча б на рівні особистісних установок.

За шкалою «Активності» половина учасників дослідження (47\%) продемонстрували високий рівень визнання цієї якості, що вказує на їхні прагнення до швидкого ритму життя $\mathrm{i}$ досягнення особистісної відповідності ньому. Середні показники активності було діагностовано у п’ятої частини вибірки (20\%), тобто швидкість їхньої діяльності певною мірою є ситуативною. У $33 \%$ респондентів зафіксовано визнання мінімального рівня активності, що може бути як наслідком захворювання, так і їі причиною - сприяти розвитку різноманітних хвороб, зокрема серцево-судинної системи. Згідно з розподілом за шкалою «Настрою» найбільша кількість осіб (47\%) визначили нейтральний «настрій». Високий рівень задекларували $40 \%$ опитаних. У цих респондентів на момент опитування позитивне налаштування переважало. I лише у $13 \%$ опитаних було діагностовано поганий настрій. Таким чином, ситуація розподілу характеризує прагнення людей до уникнення негативних думок та настрою (табл. 1).

Таблиия 1

Показники оцінювання особистісного самопочуття респондентами I вікової підгрупи (за методикою «Оперативної оцінки самопочуття, активності, настрою»)

\begin{tabular}{|l|c|c|c|}
\hline \multirow{2}{*}{ Назва шкали } & $\begin{array}{c}\text { Рівень прояву } \\
\text { характеристики }\end{array}$ & $\begin{array}{c}\text { Кількість осіб } \\
\text { (числове значення) }\end{array}$ & Відсоткові показники \\
\hline \multirow{3}{*}{ шкала «Самопочуття» } & високий & 10 & 33 \\
\cline { 2 - 4 } & середній & 12 & 40 \\
\cline { 2 - 4 } & низький & 8 & 27 \\
\hline \multirow{3}{*}{ шкала «Активності» } & високий & 14 & 20 \\
\cline { 2 - 4 } & середній & 6 & 33 \\
\cline { 2 - 4 } & низький & 10 & 40 \\
\hline \multirow{2}{*}{ шкала «Настрою } & високий & 12 & 47 \\
\cline { 2 - 4 } & середній & 4 & 13 \\
\cline { 2 - 4 } & низький & \multicolumn{2}{c}{} \\
\hline
\end{tabular}

Натомість у II віковій підгрупі розподіл відбувся по-іншому, за шкалою «Самопочуття» у групі характерним виявився низький рівень - 60 \% (18 осіб), що демонструє вплив серцевосудинних захворювань на оцінку стану здоров'я.

Таблиия 2

Показники оцінювання особистісного самопочуття респондентами II вікової підгрупи (за методикою «Оперативної оцінки самопочуття, активності, настрою»)

\begin{tabular}{|l|c|c|c|}
\hline \multicolumn{1}{|c|}{ Назва шкали } & $\begin{array}{c}\text { Рівень прояву } \\
\text { характеристики }\end{array}$ & $\begin{array}{c}\text { Кількість осіб } \\
\text { (числове } \\
\text { значення) }\end{array}$ & $\begin{array}{c}\text { Відсоткові } \\
\text { показники }\end{array}$ \\
\hline \multirow{3}{*}{ шкала «Самопочуття» } & високий & 6 & 20 \\
\cline { 2 - 4 } & середній & 6 & 60 \\
\cline { 2 - 4 } & низький & 18 & 30 \\
\hline \multirow{3}{*}{ шкала «Активності» } & високий & 9 & 37 \\
\cline { 2 - 4 } & середній & 10 & 33 \\
\cline { 2 - 4 } & низький & 11 & 20 \\
\hline \multirow{2}{*}{ шкала «Настрою } & високий & 6 & 47 \\
\cline { 2 - 4 } & середній & 10 & \\
\cline { 2 - 4 } & низький & & \\
\hline
\end{tabular}


Опрацьовані дані свідчать про те, що виявлена різниця між результатами двох вікових підгруп, зокрема, порівнявши показники варто зазначити, що основною відмінністю $\epsilon$ переважання низького рівня за різномодальними показними у II віковій пігрупи (60 р. і більше). Дана «ситуація» означає погіршення стану особистісного самосприйняття досліджуваних за усіма шкалами - самопочуття, активності, настрою - у результаті вікових змін, а також розвитку захворювань, що матиме вплив на особливості медико-психологічного консультування таких осіб. Мається на увазі те, що негативний настрій, пасивність та загальна втома будуть характеризувати клієнтів цієї підгрупи під час медико-психологічного консультування, на відміну від респондентів I групи, котрі є відкритими, активними, готовими до змін.

Висновки та перспективи подальших розвідок. Відповідно, до проведеного нами теоретико-емпіричного дослідження, ми встановили, що процес медико-психологічної консультації осіб із серцево-судинними захворюваннями $є$ особливим. Маємо на увазі те, що такий вид консультування, перш за все, вимагає від психолога-консультанта компетентності стосовно медичних особливостей серцево-судинних захворювань, їх взаємозв'язків із психологічними особливостями клієнтів. Відповідно, під впливом цих факторів, певною мірою змінюється і сам процес консультування, оскільки повинен враховуватися і вік, і індивідуальні психологічні та фізичні особливості даної категорії клієнтів.

Опираючись на емпіричні дані нашого дослідження, перспективою подальшої роботи вбачаємо у більш детальному вивченні медико-психологічного консультування осіб із серцевосудинними захворюваннями різного віку. Оскільки, клієнти певного віку характеризуються різними змінами настрою, загальною активністю та самопочуттям, що безперечно впливає на побудову медико-психологічного консультування.

\section{СПИСОК ПОСИЛАНЬ}

Белінська, Л. П. (1983). Профілактика гіпертонічної хвороби. Київ: Здоров'я.

Дроздова, І. В., Храмцова, В. Ю., Гончар, А. С., \& Яновська, С. Я. (2015). Особливості характеру хворих на артеріальну гіпертензію після перенесеного інсульту. Медицинская психология, 3 , 13-17.

Засєкіна, Л. В., \& Магдисюк, Л. І. (2018). Психологічна готовність особистості до виходу на пенсію. Луцьк : ПП Іванюк В. П.

Магдисюк, Л. І. (2016). Діагностика психологічної готовності до виходу на пенсію осіб пізньої зрілості. Наука і освіта, 2-3, 144-149.

Магдисюк, Л. І. (2014). Концептуальна матриця вікової зрілості особистості у контексті ії готовності до пенсії. Психологічні перспективи, 23, 168-178.

Магдисюк, Л. І., \& Федоренко, Р. П. (2019). Практикум психологічного консультування в юридичній сфері. Луцьк : Вежа-Друк.

Мориц, А. (2011). Секрет здорового сердияа. Минск : Попурри.

Сысоева, Н. Ю. (2008). Психологические особенности больных сердечно-сосудистыми заболеваниями. Эрудищия, 3, 25-52.

\section{REFERENCES}

Belinska, L. P. (1983). Profilaktyka hipertonichnoi khvoroby [Prevention of hypertension]. Kyiv: Zdorov'ya. [in Ukrainian].

Drozdova, I. V., Khramtsova, V. Iu., Honchar, A. S., \& Yanovska, S. Ya. (2015). Osoblyvosti kharakteru khvorykh na arterialnu hipertenziiu pislia perenesenoho insultu [Features of the character of patients with arterial hypertension after a stroke]. Medytsynskaya psykhologiya, 3, 13-17. [in Ukrainian].

Zasiekina, L. V., \& Mahdysiuk, L. I. (2018). Psykholohichna hotovnist' osobystosti do vykhodu na pensiyu [Psychological readiness of the individual for retirement]. Lutsk : PP Ivaniuk V. P. [in Ukrainian].

Mahdysiuk, L. I. (2016). Diahnostyka psykholohichnoi hotovnosti do vykhodu na pensiyu osib piznoi zrilosti [Diagnosis of psychological readiness for retirement of persons of late maturity]. Nauka $i$ osvita, 2-3, 144-149. [in Ukrainian]. 
Mahdysiuk, L. I. (2014). Kontseptualna matrytsia vikovoi zrilosti osobystosti u konteksti yii hotovnosti do pensii [Conceptual matrix of a person's age at maturity in the context of his / her willingness to retire]. Psykholohichni perspektyvy, 23, 168-178. [in Ukrainian].

Mahdysiuk, L. I., \& Fedorenko, R. P. (2019). Praktykum psykholohichnoho konsultuvannia v yurydychnii sferi [Workshop of psychological counseling in the legal field]. Lutsk : Vezha-Druk. [in Ukrainian].

Morits, A. (2011). Sekret zdorovogo serdtsa [The secret of a healthy heart]. Minsk : Popurri. [in Rassian].

Syisoeva, N. Yu. (2008). Psihologicheskie osobennosti bolnyih serdechno-sosudistyimi zabolevaniyami [Psychological characteristics of patients with cardiovascular diseases]. Eruditsiya, 3, 25-52. [in Rassian].

\title{
MEDICAL AND PSYCHOLOGICAL CONSULTING OF INDIVIDUALS WITH CARDIOVASCULAR DISEASES
}

\author{
Mahdysiuk Liudmyla \\ Candidate of Psychological Sciences, \\ Associate Professor of the Department of Practical and Clinical Psychology \\ Lesya Ukrainka Eastern European National University; \\ http://orcid.org/0000-0002-5304-933X
}

Pavlova Bohdana

student of the Faculty of Psychology and Sociology Lesya Ukrainka Eastern European National University

Gnatoyko Irina

student of the Faculty of Psychology and Sociology Lesya Ukrainka Eastern European National University

DOI https://doi.org/10.35619/prap_rv.vi14.163

Abstract. The article is devoted to the theoretical analysis of peculiarities of medical and psychological counseling of persons with cardiovascular diseases. The basic characteristics of cardiovascular diseases, their influence on the general state of health and human health are considered. The psychological factors that provoke and exacerbate the course of cardiovascular disease are also analyzed. The results of empirical research indicate the influence of psychological characteristics of personality, such as fear, mood, well-being on the development of cardiovascular diseases. Accordingly, it is important to take these features into account in the medical and psychological counseling of persons with these diseases, which, in turn, will improve the general and psychological state of the individual. The psychological determinants of assessing the quality of life of individuals with cardiovascular disease were determined not only by social circumstances, the impact of events, but also by their well-being, their state of stress and feelings.

The connection between illnesses and their impact not only on the vital activity of the individual, but also on the feeling of one's own state of health, regardless of the treatment process and the course of physiological factors, was established. The empirical data obtained can be used by practical psychologists in counseling with clients suffering from cardiovascular disease, to prevent these diseases, by increasing confidence, improving overall well-being, and reducing stressful manifestations. Also, during direct medical and psychological consultation of persons with cardiovascular diseases to reduce their negative impact on health, psychological and physical health. Theoretical and empirical data can be used by practical psychologists not only in counseling, to provide qualified psychological assistance to clients with cardiovascular diseases, but also for self-education and educational activities of all segments of the population.

Key words: emotions, medical and psychological counseling, illness, stress, cardiovascular diseases, health. 